\title{
Microbial Air Quality in Healthcare Facilities
}

\author{
Lucia Bonadonna ${ }^{1, * \mathbb{D}}$, Rossella Briancesco ${ }^{1}$, Anna Maria Coccia ${ }^{1}$, Pierluigi Meloni ${ }^{1}$ (D) Giuseppina La Rosa ${ }^{1}$ (D) \\ and Umberto Moscato 2,3
}

1 Department of Environment and Health, Italian National Institute of Health, 00161 Rome, Italy; rossella.briancesco@iss.it (R.B.); annamaria.coccia@iss.it (A.M.C.); pierluigi.meloni@iss.it (P.M.); giuseppina.larosa@iss.it (G.L.R.)

2 Department of Woman and Child Health and Public Health, Fondazione Policlinico Universitario A. Gemelli IRCCS, 00168 Rome, Italy; umberto.moscato@unicatt.it

3 Section of Occupational Medicine, Institute of Public Health, Università Cattolica del Sacro Cuore, 00168 Rome, Italy

* Correspondence: lucia.bonadonna@iss.it; Tel.: +39-06-49902317

Citation: Bonadonna, L.; Briancesco, R.; Coccia, A.M.; Meloni, P.; Rosa G.L.; Moscato, U. Microbial Air Quality in Healthcare Facilities. Int. J. Environ. Res. Public Health 2021, 18, 6226. https://doi.org/10.3390/ ijerph18126226

Academic Editor: Hae-Kwan Cheong

Received: 19 April 2021

Accepted: 4 June 2021

Published: 9 June 2021

Publisher's Note: MDPI stays neutral with regard to jurisdictional claims in published maps and institutional affiliations.

Copyright: (c) 2021 by the authors. Licensee MDPI, Basel, Switzerland. This article is an open access article distributed under the terms and conditions of the Creative Commons Attribution (CC BY) license (https:/ / creativecommons.org/licenses/by/ $4.0 /)$.

\begin{abstract}
There is increasing evidence that indoor air quality and contaminated surfaces provide an important potential source for transmission of pathogens in hospitals. Airborne hospital microorganisms are apparently harmless to healthy people. Nevertheless, healthcare settings are characterized by different environmental critical conditions and high infective risk, mainly due to the compromised immunologic conditions of the patients that make them more vulnerable to infections. Thus, spread, survival and persistence of microbial communities are important factors in hospital environments affecting health of inpatients as well as of medical and nursing staff. In this paper, airborne and aerosolized microorganisms and their presence in hospital environments are taken into consideration, and the factors that collectively contribute to defining the infection risk in these facilities are illustrated.
\end{abstract}

Keywords: healthcare facilities; indoor air; microbial contamination; surface contamination

\section{Preface}

In healthcare facilities, there is a quite high probability of contracting an infectious disease, whereas the risks associated with acute toxic effects and allergies may be lower [1]. More specifically, the risk of infection becomes prevalent in individuals with an immunodeficiency or immunosuppression that more easily leads to common infections and opportunistic infections, potentially acquired by inhalation and contact. In inpatient rooms, even during medical treatments, biological material from infected individuals can be spread throughout the environment, thereby contaminating the area and promoting the spread of pathogens [2]. In addition, in recent decades, although the use of antibiotics has proved to be an excellent instrument for preventing infections, the widespread use of these antimicrobial substances has inevitably led to the onset of events of microbial resistance to these substances [3].

Healthcare facilities can be considered dynamic environments influenced by a number of factors that collectively make an active contribution to defining the infection risk for patients, healthcare consumers, trainee doctors, temporary visitors, suppliers, contractor staff, administrative and medical personnel and other professionals. The number of occupants, their health conditions and hygiene practices, and the activities they engage in within the facility assume an important role in affecting the overall environment quality. The hygienic conditions of various sites (e.g., reception areas, inpatient wards, administrative offices, etc.), building materials, equipment, and furnishings also affect the composition of the microbial community in hospital environments. All technological systems, such as plumbing, heating, air handling and air conditioning systems, and other equipment can significantly modify the Indoor Air Quality (IAQ), becoming a potential source of bacteria, 
fungi, viruses and other organisms. Proper design and ongoing preventive maintenance can minimize hazardous conditions [4]. Microclimatic conditions (temperature, relative humidity, and air velocity) and the occurrence of accidental events (water infiltration and condensation) can also promote microbial and fungal growth, leading to harmful indoor conditions. To these factors can be added, in general, external microbial input and seasonal climatic characteristics that affect the microbiological quality of indoor air [5].

In recent years, hospital-acquired infections have constituted a significant cause of morbidity and mortality amongst immunocompromised patients and have also triggered severe medical conditions. The US Centers for Disease Control and Prevention (CDC) estimate that every year in the United States approximately 2 million patients contract an infection in hospital and that approximately 100,000 of them die [6]. However, the true extent of this phenomenon is unknown, due to the difficulties in acquiring reliable and exhaustive data. As a matter of fact, the diagnosis of hospital-acquired infections is complex and based on multiple criteria. World Health Organization (WHO) data show that of every 100 patients admitted to hospital, between 7 and 10 contract at least one infection associated with hospitalization [7].

The main sources of infection in healthcare facilities are patients and healthcare personnel, although the environment itself undeniably plays an important role. Infected patients diffuse microorganisms in the environment by releasing droplets of sputum, fluids secreted by infected wounds, excrement, urine, blood and other body fluids. On the other hand, in addition to pathogenic microorganisms, people harbor an enormous number of microorganisms composing the human microbiome, the complex community of microorganisms living in a symbiotic relationship in human microhabitats. In function of the state of immunodepression of the host, commonly non-pathogenic microorganisms can be a hazard, assuming the role of opportunistic pathogens. Pathogenic or opportunistic agents, such as Staphylococcus aureus, Streptococcus pyogenes and others can be transmitted also by asymptomatic carriers; this poses important implications for understanding and controlling infectious diseases, especially in healthcare facilities [8].

Although there is limited direct evidence proving that environmental contaminants are the cause of hospital-acquired infections, there is increasing evidence that the environment can act as a reservoir for a number of pathogenic agents and contribute to their diffusion. Besides, microorganisms are often found both on inanimate surfaces, equipment and in the indoor air of environments occupied by colonized and/or infected patients $[9,10]$.

Water distribution systems and the aerosols generated by water cooling systems can also contain pathogenic microorganisms and opportunistic pathogens of purely environmental origin for which plumbing systems provide an ideal habitat (e.g., Legionella sp., nontuberculous mycobacteria, and amoebae) [11]. Microbial contamination can also involve drugs during their distribution to patients and food during its preparation, storage and/or distribution. Unless correctly and promptly handled and disposed of, hazardous potentially infected medical waste can also be a source of environmental contamination with serious health consequences [12].

In the air, microorganisms can travel as larger droplets in a short-range, and as smaller aerosols. In this case, they are transported over longer distances by air flows or constitute part of the bioaerosol [13]. Poorly ventilated and /or crowded indoor settings can represent an increased source of spread of microorganisms that can also be also transmitted by direct contact with infectious matter or via contaminated inanimate objects. Although rare in healthcare facilities, direct contact between patients is not uncommon, and it is promoted by unapparent and/or underestimated vehicles of transmission (mobile telephones, earphones, etc.) [14].

However, it is recognized that the hands of healthcare personnel, visitors, and patients can represent the most common vector of hospital-acquired infections [15]. In these settings, hand hygiene must be considered the primary measure for reducing the risk of infections. Numerous studies have also demonstrated that white coats and uniforms worn by healthcare providers are frequently contaminated $[16,17]$. 
The microorganisms that can be spread by contact include those associated with conditions such as impetigo, abscesses, diarrhea and scabies and with antibiotic-resistant organisms (methicillin-resistant Staphylococcus aureus and vancomycin-resistant enterococci) $[18,19]$. Transmission by vectors, on the other hand, is limited to areas in which insects, arthropods and parasites are present. One non-negligible aspect regards the antibiotic-resistant bacteria that may be responsible for serious infections associated with medical care. Antimicrobial resistance is still high or is even on the increase in most European countries, especially in the case of common bacteria such as the methicillinresistant Staphylococcus aureus (MRSA), Escherichia coli, Klebsiella pneumoniae and Pseudomonas aeruginosa [20]. In Europe, cases of infection caused by completely or almost completely antibiotic-resistant bacteria have been reported: Carbapenemase-producing enterobacteriaceae (e.g., carbapenemase-producing Klebsiella pneumoniae, CPKP) and multidrugresistant Acinetobacter [21-23]. In 2019, an outbreak of carbapenem-resistant New Delhi metallo-beta-lactamase (NDM)-producing Enterobacteriaceae occurred in seven hospitals in the same region in Italy, with a total of 350 reported cases (colonized or infected individuals, including 50 cases of invasive disease) [24]. Given the high number of cases, this is an important epidemic event that reveals a shift in the epidemiology of carbapenem-resistant enterobacteria. This change reduces pharmacological treatment options, as the infections associated with the New Delhi metallo-beta-lactamase enzyme do not respond to treatment with some of the new beta-lactam and beta-lactamase inhibitor combinations [25]. In addition, NDM also presents a high risk of diffusion between healthcare facilities.

\section{Methodology}

This review focuses on airborne and aerosolized microorganisms and their presence in healthcare environments; factors that collectively contribute to defining the associated infection risk in these facilities are briefly described.

This narrative review has been carried out through the analysis of papers taken from three main databases: PubMed, SCOPUS, and DOAJ. These latter collect scientific papers from various fields and also from medicine fields, while PubMed contains citations and abstracts from biomedicine and health fields and related disciplines. The review included original papers published in peer-reviewed journals, in addition to reports and guidelines.

The search included the bacterial name plus "healthcare settings", "indoor", "air quality" and one or more of the following terms: "outbreak", "case report", "infection", "nosocomial", and "HAI" (Healthcare-associated infections). A total of 260 papers were found, and 68 articles were discarded because they were outdated or irrelevant.

In order to facilitate the research, since the selection of some specific terms did not permit an adequate sample of identified articles, several searches were made to access an appropriate number of papers.

\section{Waterborne and Bioaerosol-Associated Infections}

In indoor environments, microorganisms can be aerosolized and spread by plumbing systems [26]. As a matter of fact, it has been demonstrated that water and aqueous solutions used in healthcare facilities are often associated with hospital-acquired infections. Despite water treatment and chlorination, water in hospital distribution systems can transport variable concentrations of various autochthonous microorganisms, such as Pseudomonas sp., Legionella sp., nontuberculous mycobacteria, Acinetobacter sp., Aeromonas sp, Sphingomonas sp., Enterobacter sp., Aspergillus sp. and free-living amoebae [27]. Incorporated in a matrix of extracellular organic polymers combined with inorganic particles (biofilm), these microorganisms are present in hospital plumbing systems, hot and cold water tanks and cooling towers, as well as in wash basin pipes, shower heads and taps. Although its characteristics depend on certain parameters, and in particular on the specific microbial populations present, the biofilm promotes protection against hostile factors and, at the same time, constitutes a barrier that prevents the total eradication of the microorganisms it 
contains, with the consequent survival of microbial agents that, through the exchange of genetic material, can also acquire resistance to biocides and antibiotics.

Certain bacteria producing biofilm, such as Pseudomonas aeruginosa, Legionella, Klebsiella, Pantoea agglomerans, Enterobacter cloacae and Proteus can cause infections in hospital environments, as they are more resistant to disinfectants and antibiotics than their planktonic forms [28]. Biofilm can act as a microbial reservoir that constantly releases viable microorganisms into the water flow [29]. The aerosol spread from a shower head can potentially contaminate surfaces, medical devices and instruments, as well as endoscopes, dialysis machines, nebulizers, humidifiers and ventilators [30], by means of movement of air in indoor environments. The routes of transmission of waterborne pathogenic agents include direct and indirect contact, use of water for drinking and washing and inhalation of the bioaerosol of contaminated water.

In hospital environments, Pseudomonas aeruginosa and Legionella pneumophila are the most significant waterborne pathogens [31,32]. P. aeruginosa is often associated with hospital-acquired infections, especially among patients on mechanical ventilation or immunocompromised patients in Intensive Care Units (ICUs) [33]. In these environments, it is assumed that the main reservoir of $P$. aeruginosa is the patient's endogenous flora and that horizontal transmission between patients is the most common source of infection associated with this microorganism. As has been demonstrated by a number of studies, patient-to-patient spread via the hands of healthcare staff and the propagation of the bacterium by means of surfaces are sources of $P$. aeruginosa infection [34,35].

In recent years, the use of molecular typing methods has made it possible to identify a significant source of exogenous strains of P. aeruginosa, isolated from tap water supply in ICUs. A review of prospective epidemiological studies has shown that between $14.2 \%$ and $50 \%$ of cases of patient infection/colonization was caused by genotypes found in the ICU water supply [33].

The most common form of transmission of Legionella is inhalation of contaminated aerosols produced in conjunction with water sprays, jets or mists. Infection can also occur by aspiration of contaminated water, particularly in susceptible hospital patients. Worldwide, waterborne Legionella pneumophila is the most common cause of cases, including outbreaks. Already by the end of the 1970s, it had emerged that Legionella could be considered a serious risk for immunosuppressed patients, especially in healthcare facilities [36-38]. This type of transmission constitutes a considerable risk for patients with chronic lung disease, those undergoing general anesthesia, and all immunosuppressed subjects. In hospital settings, patient immunodeficiency combined with other risk factors results not only in an increased risk of infection, but is also associated with a higher incidence of morbidity than in other types of facility. In 2017, in Italy, of the 2014 reported cases of Legionnaire's disease, $6.2 \%$ involved healthcare facilities. Specific reservoirs of Legionella in these environments can be respiratory devices, point of use (showers, taps), humidifiers and cooling towers [39,40].

Non-tuberculous mycobacteria (NTM), also known as environmental or atypical mycobacteria, are responsible for hospital-acquired infections transmitted via inhalation route or direct contact. The structure of their cell wall, which is particularly rich in long-chain fatty acids, and their ability to form biofilm contribute to their extraordinary resistance to chemical substances and allow them to persist in the environment for long periods [41]. Indeed, NTM are commonly found in water distribution systems and they can be aerosolized via showers and taps $[42,43]$. In this case, a microbiological survey conducted by the authors confirmed the presence of NTM in a hospital plumbing system. Following a number of cases of atypical mycobacteria infection in hospital units, a monitoring study was conducted to identify the sources of risk, to correlate patient exposure with the concentration of NTM in critical points (showerheads and aerators) and to issue corrective measure guidelines. The concentration of NTM observed was between $2 \times 10^{2}$ and $4 \times 10^{4} \mathrm{CFU} / \mathrm{L}$ and the mycobacteria species isolated and identified included both species of opportunistic pathogens (M. intracellulare, $M$. chelonae, M. llatzerense, M. gordonae) and harmless environ- 
mental species [44]. As the risk resulting from the presence of NTM in water cannot be controlled using conventional water disinfection procedures, the installation of filters at the point of use could be the most appropriate option for minimizing exposure.

Hospital water distribution systems can also constitute potential reservoirs of filamentous fungi (molds) such as Aspergillus sp., Zygomycetes, Fusarium sp., and others [45]. Ubiquitous in nature, molds grow and survive in all types of indoor and outdoor environments. Subjects can be exposed by skin contact, inhalation or ingestion. Inhalation is thought to be the main mechanism of exposure to fungi or their fragments and components [46]. Most fungal spores have an aerodynamic diameter ( $\mathrm{Da})$ of 2-10 $\mu \mathrm{m}$, dimensions that allow them to deposit in both the upper and lower airways of humans [13]. As a rule, severely immunosuppressed subjects have a higher risk of contracting severe fungal infections.

\section{Air Treatment Systems and Airborne Diffusion of Microorganisms}

The airborne infectious particles of microorganisms can take the form of either individual units of infectious load or clusters, usually inside or on the surface of biological matter, known as a "carrier" (the Flügge droplets generated by saliva or nasal mucus and/or pharyngeal or expectorate), or even clusters with polar charges, or that are adsorbed on the surfaces of suspended inert particulate matter [13].

Airborne microorganisms generally do not pose a risk to healthy individuals, whereas pathogenic microorganisms as well as opportunistic environmental agents can be responsible for infections in immunosuppressed subjects in hospital settings. Indoor air quality in healthcare facilities is, therefore, critical and represents an important risk factor.

One of the certainly most important factors affecting indoor air is the efficiency of air handling systems, which can not only be an effective way to prevent airborne disease transmission, but also a way of reducing the spread of chemical and physical contaminants. Besides, air treatment (Heating, Ventilation and Air-Conditioning, HVAC) systems, human activities carried out in the various areas and the presence of subjects with medical conditions can also influence the quality of the circulating air. This is also a consequence of technical choices concerning these systems, sometimes dictated by design choices that are unfit or inadequate for hospital environments, with regard to both the high costs associated with the cleaning of the utility system and the complex or difficult maintenance that make HVAC systems difficult to effectively manage, with a consequent risk for patients and staff [47].

Therefore, air treatment/ventilation systems can capture biological agents through air intake or recirculation (active in many centralized HVAC systems in order to reduce the system's energetic impact, but extremely hazardous given the tendency to increase the infectious load in environments where high levels of microorganisms are present). Consequently, they can become either a source of production of microorganisms or molds that find, in the particulate matter inside the system's pipes, an ideal growth substrate, or a means for distant diffusion of contaminants due to the capacities and air flows generated. Inside the ducts, the humidity generated by condensation, together with the dust that accumulates over time, can promote microbial growth and multiplication. Therefore, in hospital environments, specific air management permitting suitable ventilation conditions is of paramount importance. This is particularly important when associated with appropriate filtration and/or the definition of appropriate pressure differentials between environments by means of air flows and turnover identified during the design phase and not subsequently altered in line with changes in the way the healthcare environments are used, as all too often occurs [47].

It has been ascertained that inadequate ventilation is often responsible for the airborne transmission of respiratory viruses [48]. Although the range of diffusion of the microorganisms in air can be very long, it depends on a number of factors, as respiratory activity results in the release of particles of varying dimensions, whose distribution depends on the conditions in which they are released. Whereas infectious particles, as in the case of SARS-CoV-2, with a diameter of between 0.5 and $50 \mu \mathrm{m}$ (small droplets), can take from 
hours $(>41 \mathrm{~h}$ ) to seconds ( $>28 \mathrm{~s}$ ) to settle within a range of $1 \mathrm{~m}$ before falling to the ground, large droplets, with a diameter of $200 \mu \mathrm{m}$, take between 2.6" and 0.1" to settle within $1 \mathrm{~m}$ from the source. Consequently, these latter represent a minimal or negligible risk of distant transmission, or spread at long distance with HVAC systems. As the probability of a droplet containing virions is proportionate to its volume (therefore to the third power of the diameter), it follows that in the air viruses are in any case carried primarily via "large droplets" that fall rapidly to the ground. Nevertheless, part of the viral units can be released, as mentioned previously, by medium and small droplets that, due to their size, can remain airborne for a long time, thereby forming aerosols of droplet nuclei that can be easily carried by airstreams in indoor environments.

Droplets larger than $5 \mu \mathrm{m}$ are primarily produced by coughing, sneezing, singing or speaking. In healthcare facilities, certain medical practices, such as fluid aspiration and bronchoscopy, can also cause the diffusion of particles of this size. The most relevant infections transmitted by droplets are measles, chicken pox, tuberculosis, meningococcal disease, Mycoplasma pneumoniae, SARS-CoV-2 (Severe Acute Respiratory Syndrome coronavirus 2), and influenza. Generally speaking, the airborne transmission of infection only regards microorganisms with a low infective dose and takes place following the release of large amounts of microorganisms into the air. The key factors that influence the level of the microbial load in indoor air of a healthcare facility include the number of occupants and the level of relative humidity, which is in turn associated with the specific position of the rooms inside the facility. In general, this influences an HVAC system's ability to be able to maintain adequate air flow rate and turnover conditions to maintain pressure differentials, when required, especially in critical environments, such as operating theatres and ICUs. This is particularly important considering that the filtration of the systems, despite being applied with high-efficiency filters in healthcare facilities, has not yet shown full efficiency towards those microorganisms-usually viruses-with submicronic dimensions and that are, therefore, smaller than their filtration capacity (e.g., rubella, certain Orthomyxoviruses, etc.). The diagram in Figure 1, provides a simplified overview of critical issues associated with the sources and risk factors for the diffusion of contaminants by HVAC systems [47,49-51].

Structural and Management Critical Issues of the HVAC System: Sources

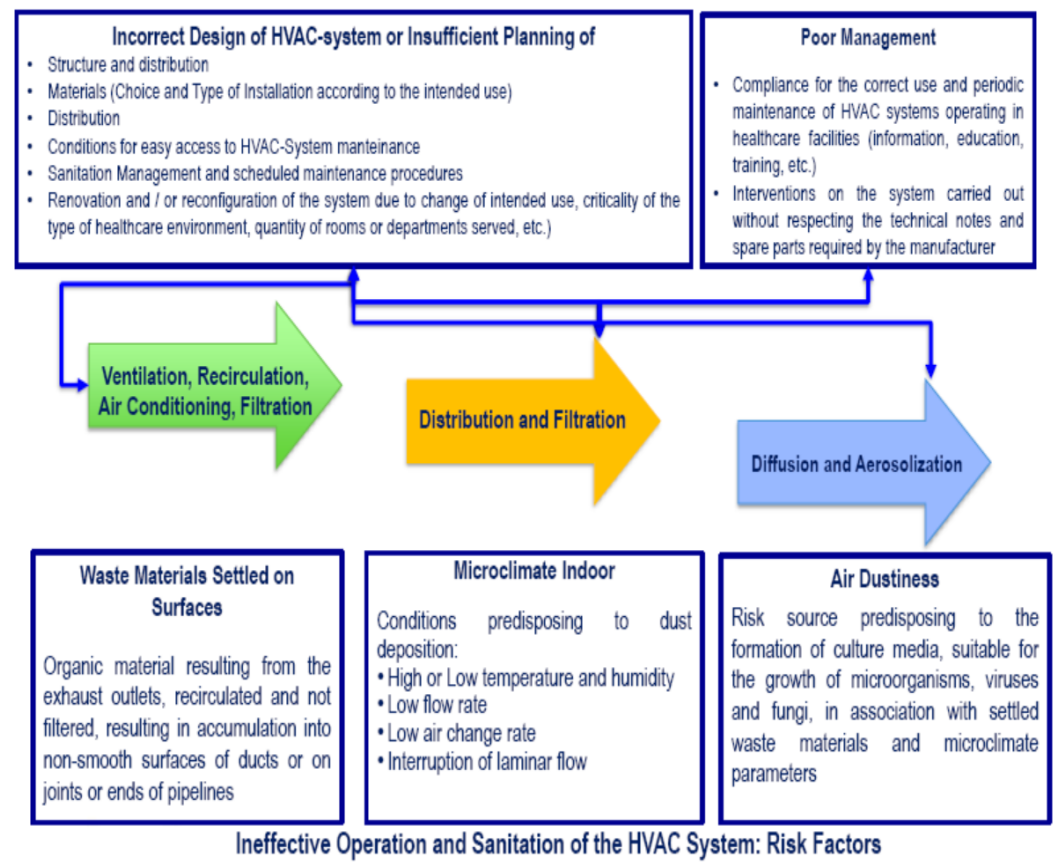

Figure 1. Sources, conditions and risk factors of contamination of the HVAC system: simplified scheme [47]. 
However, it should be noted that healthcare facilities pose an additional problem with regard to the correct management of HVAC systems in order to reduce their impact on the spread of microorganisms in the air. As a matter of fact, the cleaning and maintenance of the units and ducts must be performed with the system switched off and when environments into which the air is released are unoccupied, given the probability of producing dust downstream of the system and consequently contaminating areas with a "dust burst", despite the implementation of a system decontamination procedure as extensively described in the literature $[52,53]$.

It goes without say that, unlike the case for residential household systems, it is difficult to achieve these conditions in hospital environments, where in emergency departments or ICUs, "shutting down" facilities for several days is not only costly but also impractical. Therefore, in order to express a risk matrix according to hospital environment and the susceptibility of the occupants (remembering that, in addition to patients, healthcare professionals and visitors could present forms of immunodepression), for the management of the cleaning and maintenance of HVAC systems in healthcare facilities, the matrix reported in Figure 2 could be used, considering that cleaning and maintenance status greatly influences the possibility of microorganism spread by or via the units $[47,53]$.

\begin{tabular}{|c|c|c|c|c|c|}
\hline & Risk Matrix & Susce & ibility with H & AC-systen & \\
\hline & At-risk Groups & $\begin{array}{l}\text { Maximum Level } \\
\text { Filtration, Maintenance } \\
\text { and Sanitizing }\end{array}$ & $\begin{array}{l}\text { Medium Level } \\
\text { Filtration, } \\
\text { Maintenance and } \\
\text { Sanitizing }\end{array}$ & $\begin{array}{l}\text { Minimum Level } \\
\text { Filtration, } \\
\text { Maintenance } \\
\text { and Sanitizing }\end{array}$ & $\begin{array}{l}\text { Lack HVAC- } \\
\text { Systems } \\
\text { Management }\end{array}$ \\
\hline 1 & $\begin{array}{l}\text { - Hospital social areas (areas for public or communication) } \\
\text { - Administrative offices } \\
\text { - Inpatient areas not occupied (by patients) }\end{array}$ & Minimum & Medium & Medium & Medium-High \\
\hline 2 & $\begin{array}{l}\text { - Surgeries and external access areas (except for out-patients falling } \\
\text { under levels } 3 \text { or } 4 \text { ) } \\
\text { - Admission/discharge areas } \\
\text { - Patient areas with patients not pertaining to the levels } 3 \text { or } 4\end{array}$ & Minimum & Medium & Medium-High & High \\
\hline 3 & $\begin{array}{l}\text { - Emergency Unit } \\
\text { - Radiology and Nuclear Medicine } \\
\text { - Day Surgery and areas in Operating Theatres } \\
\text { - Post Operative Intensive Care or Post Anaesthesia } \\
\text { - Laboratories } \\
\text { - Echocardiography } \\
\text { - Physiotherapy Areas } \\
\text { - Neonatology and paediatrics } \\
\text { - } \text { Intiatrics and long-term care } \\
\text { - Internal Medicine and General Surgery }\end{array}$ & Minimum & Medium-High & $\begin{array}{l}\text { Medium-High } \\
- \\
\text { High }\end{array}$ & $\begin{array}{l}\text { Very } \\
\text { High }\end{array}$ \\
\hline 4 & $\begin{array}{l}\text { - Intensive Care Units } \\
\text { - Operating Theatres } \\
\text { - Anaesthesia induction rooms } \\
\text { - Oncology departments for outpatients } \\
\text { - Transplant wards (bone marrow and others) and outpatient clinic for } \\
\text { transplant patients } \\
\text { - Dialysis units } \\
\text { - Inpatient wards with HIV or immunosuppressed patients } \\
\text { - Areas of angiography or hemodynamic and cardiology } \\
\text { - Endoscopy Areas } \\
\text { - Pharmacy, pharmaceutical preparation and parenteral nutrition } \\
\text { - Sterilization Unit, Sterile or clean instruments spaces }\end{array}$ & $\begin{array}{l}\text { Minimum } \\
\text { Medium-High }\end{array}$ & $\begin{array}{l}\text { Medium-High } \\
- \\
\text { High }\end{array}$ & High & Maximum \\
\hline
\end{tabular}

Figure 2. Matrix of the risk level to which the patient is exposed in air conditioned hospital environments [47].

\section{Mold Infections in Hospital Environments}

Molds are often observed indoor in healthcare settings, especially during construction and maintenance works. Fungal spores have a slow sedimentation time and remain airborne for a long time, although they are always present in dust and on surfaces and clothing, even in conditions of low humidity $[54,55]$. Hospitalized subjects, who have a weak immune response, are more susceptible than healthy individuals to infection by the 
mesophilic fungi commonly present in nature; in recent decades, high mortality rates have been reported amongst transplant patients and those with leukemia [56-60].

A study conducted following a number of cases of postsurgical infections at a transplant center in Rome included a qualitative and quantitative analysis of the bacteria and molds present indoor and on surfaces of a surgery block (operating theatres, ICUs, surgery ward, treatment rooms and adjacent corridors) [61]. Low mold concentrations were observed in both the air samples and on the surfaces $\left(0-70 \mathrm{CFU} / \mathrm{m}^{3}\right.$, and $0-21 \mathrm{CFU} / \mathrm{cm}^{2}$, respectively). In addition to the various opportunistic pathogens isolated (Alternaria infectoria, Alternaria tenuissima, Epicoccum nigrum, Purpureocillum lilacinum, Cryptococcus laurentii), opportunistic molds of environmental origin belonging to the genera Penicillium, Aspergillus, Cladosporium, Mucor, Stemphylium, Conidiobolus and Trichoderma were also observed. As regards the bacterial component, the concentrations of biological agents in air varied from 9 to $174 \mathrm{CFU} / \mathrm{m}^{3}$, with the highest values observed in the emergency departments. Staphylococcus aureus and other opportunistic species of the Staphylococcus genus were isolated in many areas. The known opportunistic bacterial species Leclercia adecarboxylata, Enterobacter cloacae, Bacillus cereus and Kokuria varians were also detected. In general, moderate microbial contamination was observed on the surfaces examined, with the exception of a high concentration value $\left(>1 \times 10^{3} \mathrm{CFU} / \mathrm{cm}^{2}\right)$ found on a trolley used for supplying drugs to patients: Pseudomonas stutzeri, a known opportunistic pathogen, was detected [61].

\section{Surfaces as a Potential Source of Infection}

In healthcare facilities, beds, sheets, floors, walls, furniture and medical equipment are often subject to microbial colonization able to survive for long periods [62]. Whereas this can represent a limited risk in domestic settings, in healthcare facilities, the presence of immunocompromised patients can constitute an additional health risk. Biological agents, as part of the microbiome of inpatients, may be transmitted to patients by healthcare staff and visitors, via the particulate matter deposited on surfaces and resuspended by the natural process of convection due to air streams and HVAC systems. A room that was previously occupied by a patient colonized or infected by methicillin-resistant Staphylococcus aureus (MRSA), vancomycin-resistant enterococci (VRE), Clostridium difficile, multidrug-resistant Acinetobacter or multidrug-resistant Pseudomonas, may constitute an additional risk factor for the newly hospitalized patient [63-65].

Among the opportunistic, multiple antibiotic-resistant pathogens detected in hospital settings, the yeast Candida auris was first described in 2009. It has been identified as an emerging pathogen and causes candidiasis, currently identified as one of the most common hospital-acquired infections in debilitated or immunocompromised individuals or those undergoing surgery. Its exact route of transmission is still unclear. However, the preliminary evidence suggests that it spreads in healthcare facilities through contact with contaminated surfaces or interpersonal contact. Candida auris is an opportunistic pathogen because it can be isolated also in asymptomatic subjects [66]. This yeast has caused a number of epidemics worldwide, and has been reported in Japan, South Korea, India, Pakistan, Venezuela, Brazil, South Africa, Kuwait, USA, Canada, Israel, Britain and Spain, as well as many isolated cases. In the United States, between May 2013 and April 2017, 61 cases of infection were recorded by the CDC, in addition to 32 cases of colonization in asymptomatic subjects. In various outbreaks worldwide, a particularly high mortality rate was observed (30\% and $75 \%)$. However, many deceased patients already had seriously compromised clinical conditions, which were further complicated by failure to correctly identify the biological agent. In a study conducted in India, 332 samples (32\%) collected from different surfaces in a healthcare facility were found to be contaminated: $203(61 \%)$ by Gram-negative bacteria, 216 (65\%) by Gram-positive cocci and $52(16 \%)$ by fungi [67]. The most commonly contaminated samples were collected from humidifiers, refrigerators, incubators, medication trolleys, trays and boxes and intensive care equipment. In a pediatric ICU, endemic multidrug-resistant Klebsiella pneumoniae was frequently isolated [68,69]. 
The main hospital-acquired pathogens able to survive on inanimate surfaces, and the duration of their persistence are listed in Tables 1 and 2. In most cases, humidity improves the persistence of different types of bacteria (e.g., Chlamydia trachomatis, Listeria monocytogenes, Salmonella typhimurium, Pseudomonas aeruginosa, Escherichia coli), whereas Staphylococcus aureus alone survives longer at lower humidity values. In the environment, Gram-positive bacteria survive longer than Gram-negative bacteria [70-74].

Table 1. Pathogenic bacteria and fungi detected in fomites and hospital environments, their survival and references.

\begin{tabular}{|c|c|c|}
\hline Bacteria & $\begin{array}{l}\text { Duration of Survival on } \\
\text { Inanimate Surfaces (Range) }\end{array}$ & References \\
\hline Acinetobacter baumannii (including MRD) & 2 days $->4$ months & [75-77] \\
\hline Bordetella pertussis & $3-5$ days & [78] \\
\hline Burkolderia cepacia & $>1$ week & [79] \\
\hline Campylobacter jejuni & $15 \mathrm{~min}-7 \mathrm{~h}$ & {$[80]$} \\
\hline Chlamydia pneumonae/tracomatis & $30 \mathrm{~min}-\leq 30 \mathrm{~h}$ & {$[81,82]$} \\
\hline Chlamydia psittaci & 15 days to months & {$[83]$} \\
\hline Clostridium difficile (spores) & 5 months & [84] \\
\hline Corynebacterium diphtheriae & 7 days -6 months & [78] \\
\hline Corynebacterium pseudotuberculosis & 1-8 days & [85] \\
\hline Enterococcus faecalis/faecium (including VRE) & 5 day -3 months & [86-89] \\
\hline Escherichia coli (including pathogenic) & $<1 \mathrm{~h}-28$ days & {$[77,90,91]$} \\
\hline Haemophilus influenzae & 12 days & [9] \\
\hline Helicobacter pylori & $\leq 90 \mathrm{~min}$ & [92] \\
\hline Klebsiella pneumoniae & 1 h- 6 weeks & [93-96] \\
\hline Listeria monocitogenes & at least $24 \mathrm{~h}$ & [97] \\
\hline Mycobacterium tuberculosis & 10-120 day & [98] \\
\hline Neisseria gonorrhoeae & $>24 \mathrm{~h}$ & [99] \\
\hline Neisseria meningitides & $72 \mathrm{~h}$ & [100] \\
\hline Proteus mirabilis & $4 \mathrm{~h}-26$ days & {$[94]$} \\
\hline Proteus vulgaris & 1-2 days & [98] \\
\hline Pseudomonas aeruginosa & $5 \mathrm{~h}-33$ days & {$[93,101]$} \\
\hline Salmonella enterica serovar Abony & $1->24 \mathrm{~h}$ & [102] \\
\hline Salmonella enterica serovar Enteritidis & $1-48 \mathrm{~h}$ & {$[93,102]$} \\
\hline Salmonella enterica serovar Typhimurium & 5 h-12 weeks & {$[93,103,104]$} \\
\hline Salmonella typhi & $6 \mathrm{~h}-4$ weeks & [98] \\
\hline Salmonella spp. & at least 30 days & [105] \\
\hline Serratia marcescens & $<1 \mathrm{~h}-11$ days & {$[93,94]$} \\
\hline Shigella spp. & $1.5-4 \mathrm{~h}$ & [106] \\
\hline Staphylococcus aureus (including MRSA) & $6 \mathrm{~h}-12$ days & {$[77,107,108]$} \\
\hline Stenotrophomonas maltophylia & 2-7 days & [101] \\
\hline Streptococcus pneumoniae & 1 day up 30 months & {$[109,110]$} \\
\hline Streptococcus pyogenes & 3 days -6.5 months & {$[110,111]$} \\
\hline Yersinia pestis & up to 5 days & [112] \\
\hline \multicolumn{3}{|l|}{ Yeasts and Molds } \\
\hline Candida albicans & 1-120 days & {$[113,114]$} \\
\hline Candida auris (MRD) & 3-14 days & [114-117] \\
\hline Cryptococcus neoformans & 30 days & [101] \\
\hline Aspergillus spp. (conidia) & 1 year & {$[118,119]$} \\
\hline Aspergillus flavus & $2-30$ days & {$[120,121]$} \\
\hline Aspergillus fumigatus & $1-30$ days & {$[101,120,121]$} \\
\hline Aspergillus niger & 1-30 days & [120-122] \\
\hline Fusarium spp. & $48 \mathrm{~h}->30$ days & {$[120,121,123]$} \\
\hline Mucor spp. & $16->30$ days & [121] \\
\hline Paecilomyces spp. & $<1-11$ days & [120] \\
\hline Penicillum crysogenum & $6-120 \mathrm{~h}$ & [121] \\
\hline
\end{tabular}


Table 2. Viruses detected in fomites and hospital environments, their survival and references.

\begin{tabular}{|c|c|c|}
\hline Viruses & $\begin{array}{c}\text { Duration of Survival on } \\
\text { Inanimate Surfaces (Range) }\end{array}$ & References \\
\hline Adenovirus & $1 \mathrm{~h}->12$ weeks & [124-131] \\
\hline Astrovirus & 7-90 days & [126] \\
\hline Caliciviridae & $<5$ min $\rightarrow 168$ days & [132-137] \\
\hline Coronavirus (SARS-CoV-2, & & \\
\hline $\begin{array}{l}\text { SARS-CoV, MERS-CoV, HCoV -229E, } \\
\text { HCoV -OC43, HCoV -NL63) }\end{array}$ & 30 min $->8$ days & {$[131,138-150]$} \\
\hline Coxsackie virus & 2-5 weeks & {$[125,130,151]$} \\
\hline Cytomegalovirus & $1 \mathrm{~h}-4 \mathrm{~h}$ & {$[152,153]$} \\
\hline Echovirus & $48 \mathrm{~h}-7$ days & {$[127,154]$} \\
\hline Filoviruses & 2 days $->32$ days & {$[155,156]$} \\
\hline Hepatitis A Virus & $2 \mathrm{~h}->60$ days & {$[126,129,132,157]$} \\
\hline Hepatitis B Virus & $>14$ days & {$[158,159]$} \\
\hline Hepatitis C Virus & 5 days -6 weeks & [160-162] \\
\hline Human Immunodeficiency Virus & $>5$ days & [163-165] \\
\hline Herpes Simplex Virus, Type 1 and 2 & $4.5 \mathrm{~h}->8$ weeks & $\begin{array}{c}{[125,130,131,151,163]} \\
{[166]}\end{array}$ \\
\hline Human Metapneumovirus (HMPV) & $2-8 \mathrm{~h}$ & [167] \\
\hline Influenza Virus & 1-2 days & {$[127,147,168-172]$} \\
\hline Parainfluenza Virus & $<0.5 \mathrm{~h}->8 \mathrm{~h}$ & [169] \\
\hline Feline Norovirus and Calicivirus & $8 \mathrm{~h}-7$ days & {$[133,134]$} \\
\hline Papillomaviridae & $>7$ days & [173] \\
\hline Papovavirus & 8 days & [163] \\
\hline Parvovirus & $>1$ year & [163] \\
\hline Poliovirus Type 1 & $4 \mathrm{~h}->60$ days & {$[129,154,157,163,174]$} \\
\hline Poliovirus Type 2 & 1 day-8 weeks & {$[125,126,130]$} \\
\hline Poxviridae & $<1$ day-56 days & {$[125,175]$} \\
\hline Pseudorabies Virus & $>/=7$ days & [176] \\
\hline Respiratory Syncytial Virus & $0.5 \mathrm{~h}-6$ months & [177] \\
\hline Rhinovirus & $2 \mathrm{~h}-7$ days & {$[178,179]$} \\
\hline Rotavirus & $1 \mathrm{~h}->60$ days & {$[126,129,180-183]$} \\
\hline Vaccinia Virus & $3->20$ weeks & {$[125,184]$} \\
\hline
\end{tabular}

The immune status of subjects in the highest infection risk areas and the procedures they undergo make patients particularly vulnerable to microbial infections. Inside a surgery block, microbial contamination can be primarily attributed to the airborne microorganisms convey by surgical staff and patients; other potential sources of contamination are controlled-contamination HVAC systems and non-sterile instruments, which have an impact on environmental conditions. In this context, the transmission of Mycobacterium chimaera in hospital environments, a bacterium found in biofilm and tap water, seems to be correlated with the introduction in areas at risk of medical instruments and surgery devices. With regard to specific appliances, there have been recent reports of cases of invasive cardiovascular Mycobacterium chimaera infections. M. chimaera can cause lung infections, especially in immunocompromised patients [70,71]. The first report on $M$. chimaera infections following heart surgery infections was published in 2013 [72]. Other studies described cases of Mycobacterium chimaera infection with endocarditis of the artificial heart valve and infections of the vascular graft and an epidemiological connection was established with the heater-cooler units (HCU) used during the surgical procedure [73]. Since then, further cases of $M$. chimaera have been reported associated with the use of these systems in patients undergoing open heart surgery in various European countries (France, Germany, Ireland, Holland, Spain, United Kingdom and Switzerland, as well as the United States, Canada, Australia and Hong Kong; the first report in Italy was in June 2018) [74]. Heating-cooling units are classified as class IIb medical devices and are used during cardiothoracic surgery procedures involving the heating/cooling of the patient. These devices consist of tanks that supply water at a controlled temperature to heat exchangers and to heating/cooling 
blankets, via water circuits. To date, it has not been possible to identify the equipment's exact role in transmitting $M$. chimaera to the environment. However, the manufacturers of the equipment have issued guidelines and safety warnings to operators.

\section{Conclusions}

Healthcare-associated infections (HAIs) have a special place among the risks associated with health and social care, due to their size, complexity of determinants, and epidemiological trends. The clinical-economic impact is significant: according to a WHO report healthcare-associated infections cause prolonged hospital stays, long-term disability, increased antibiotic microbial resistance (AMR), additional costs, and excess mortality [185].

Cassini et al. estimated that 2,609,911 new cases of HAIs occur every year in the European Union and European Economic Area [186]. In Italy, the number of HAIs would appear to vary from 450,000 to 700,000 per year, with $30 \%$ of infections being preventable [187].

The role of the hospital environment in the transmission of HAIs is still a matter of debate in scientific communities. In fact, the global burden of healthcare-associated infection is unknown because of the difficulty of gathering reliable diagnostic data. However, evidence seems to confirm that healthcare settings represent a large reservoir of pathogenic and opportunistic microorganisms from different matrices such as air, surfaces, medical equipment and water systems. Moreover, spread of pathogens can result from inpatients themselves, visitors, and healthcare personnel. In addition, the use of antibiotic therapies causes the selection of multi-resistant pathogens that spread within the facility, increasing the risk for exposed individuals.

Despite efforts to implement preventive measures, it is still difficult to record HAIs according to the source of infection.

However, it can be argued that water is one of the most reported source of infection because of possibility to verify its quality. Water safety in healthcare settings is a top priority and a constant challenge for these facilities. Control and management of water quality issues in healthcare facilities is a topic of great interest and certainly intersects with assessment and management of air quality. In fact, aerosolization of contaminated water from showers, faucets, and medical devices poses a real health risk in settings such as hospitals and nursing homes. In addition, it is recognized that the quality standards prescribed to date by water quality legislation have not been able to ensure the safety of particularly vulnerable populations or individuals. In fact, they are requirements aimed at ensuring the quality of water intended for consumption by a healthy population. Nevertheless, it is known that colonization of plumbing or ventilation systems by Legionella can often cause Legionnaires' disease in healthcare facilities. Exposure to the risk of acquiring the disease occurs through the airways as a result of inhalation of aerosols of contaminated water released from showers, air humidifiers and medical devices, including dental equipment [188].

Conversely, among the countless sources of HAIs, one of the most difficult environmental components to study and assess is certainly air from a microbiological perspective, and still more in healthcare facilities where several factors have a large impact on the air quality.

The need for multiple strategies to control the spread of pathogenic microorganisms and adoption of appropriate preventive measures could allow identification of the real role that healthcare settings have in the spread of infections. Nevertheless, at an international level, there is no consensus regarding the methods to be adopted in order to measure and analyze airborne biocontamination, in particular in high-risk areas, and official methods and frequency of sampling and analysis cannot be universally adopted for each circumstance. These difficulties reflect the current situation: although there are recommendations from international agencies and institutions, there are no legislative values or health-based standards for the microbiological parameters of indoor air quality due to the difficulties encountered in associating the data of the microbiological tests with those of epidemiological investigations. 
A safe environment plays an important role in the prevention of HAIs and the spread of AMR. Many factors, including the design, organization and management of the healthcare facility, availability for safe water, appropriate sanitation, air quality and efficiency of the air treatment equipment, can significantly influence the transmission of infections. Many infection prevention and control measures, including hand hygiene, are simple, lowcost and effective; however, they require awareness by healthcare providers and personnel.

From the literature, the need for an efficient control of microbial contamination on surfaces in hospital environments even strongly emerges. Indeed, these surfaces can easily represent significant sites of colonization from microorganisms that may contribute to the transmission of HAIs.

Control of surface bacterial load is routinely addressed with the use of conventional chemical-based soap/disinfectants. However, these can be ineffective in preventing recontamination and can select strains resistant to disinfectants themselves. Recently, cleaning agents containing probiotic agents have been proposed for hospital sanitation and have been shown to stably reduce surface pathogens up to $90 \%$ more than conventional disinfectants [189].

Infection control programs are defined by the WHO and CDC [185,190-192]. Improving HAI monitoring systems and implementing standard procedures to reduce microbial spread in higher-risk areas should be the primary goals, especially during public health emergencies.

Author Contributions: Study conception and design, L.B. and U.M.; Analysis and interpretation of data, L.B., R.B., A.M.C., G.L.R. and P.M.; writing-original draft preparation L.B., R.B., A.M.C. and G.L.R.; Critical revision and editing, L.B. and U.M. All authors have read and agreed to the published version of the manuscript.

Funding: This research received no external funding.

Institutional Review Board Statement: Ethics approval was not required for this study.

Informed Consent Statement: Formal consent is not required for this type of study.

Data Availability Statement: No datasets were generated or analyzed during the current study.

Acknowledgments: We thank Pamela Mancini for contributing in searching databases.

Conflicts of Interest: The authors declare no conflict of interest.

\section{References}

1. Bereket, W.; Hemalatha, K.; Getenet, B.; Wondwossen, T.; Solomon, A.; Zeynudin, A.; Kannan, S. Update on bacterial nosocomial infections. Eur. Rev. Med. Pharmacol. Sci. 2012, 16, 1039-1044. [PubMed]

2. Cohen, B.; Spirito, C.M.; Liu, J.; Cato, K.D.; Larson, E. Concurrent detection of bacterial pathogens in hospital roommates. Nurs. Res. 2019, 68, 80-83. [CrossRef] [PubMed]

3. Scarafile, G. Antibiotic resistance: Current issues and future strategies. Rev. Health Care 2016, 7, 16. [CrossRef]

4. Saran, S.; Gurjar, M.; Baronia, A.; Sivapurapu, V.; Ghosh, P.S.; Raju, G.M.; Maurya, I. Heating, ventilation and air conditioning (HVAC) in intensive care unit. Crit. Care 2020, 24, 194. [CrossRef] [PubMed]

5. Tang, J.W. The effect of environmental parameters on the survival of airborne infectious agents. J. R. Soc. Interface 2009, 6 (Suppl. 6), S737-S746. [CrossRef] [PubMed]

6. Klevens, M.; Edwards, J.R.; Richards, C.L.; Horan, T.C.; Gaynes, R.P.; Pollock, D.A.; Cardo, D.M. Estimating health care-associated infections and deaths in U.S. hospitals, 2002. Public Health Rep. 2007, 122, 160-166. [CrossRef]

7. World Health Organization (WHO). Report on the Burden of Endemic Health Care-Associated Infection Worldwide; World Health Organization Press: Geneva, Switzerland, 2011.

8. Chisholm, R.H.; Campbell, P.T.; Wu, Y.; Tong, S.Y.C.; McVernon, J.; Geard, N. Implications of asymptomatic carriers for infectious disease transmission and control. R. Soc. Open Sci. 2018, 5, 172341. [CrossRef] [PubMed]

9. Kramer, A.; Schwebke, I.; Kampf, G. How long do nosocomial pathogens persist on inanimate surfaces? A systematic review. BMC Infect. Dis. 2006, 6, 130. [CrossRef]

10. Weber, D.J.; Anderson, D.; Rutala, W.A. The role of the surface environment in healthcare-associated infections. Curr. Opin. Infect. Dis. 2013, 26, 338-344. [CrossRef] [PubMed]

11. Decker, B.K.; Palmore, T.N. Hospital water and opportunities for infection prevention. Curr. Infect. Dis. Rep. 2014, 16, 432. [CrossRef] 
12. Pande, S.; Dwive, A.K. Nosocomial infections through hospital waste. Int. J. Waste Resour. 2016, 6. [CrossRef]

13. Nazaroff, W.W. Indoor bioaerosol dynamics. Indoor Air 2016, 26, 61-78. [CrossRef] [PubMed]

14. Messina, G.; Ceriale, E.; Lenzi, D.; Burgassi, S.; Azzolini, E.; Manzi, P. Environmental contaminants in hospital settings and progress in disinfecting techniques, BioMed. Res. Inter. 2013, 2013, 1-8. [CrossRef]

15. English, K.M.; Langley, J.M.; McGeer, A.; Hupert, N.; Tellier, R.; Henry, B.; Halperin, S.A.; Johnston, L.; Pourbohloul, B. Contact among healthcare workers in the hospital setting: Developing the evidence base for innovative approaches to infection control. BMC Infect. Dis. 2018, 18, 184. [CrossRef]

16. World Health Organization (WHO). Guidelines on Hand Hygiene in Health Care; World Health Organization Press: Geneva, Switzerland, 2009.

17. Haverstick, S.; Goodrich, C.; Freeman, R.; James, S.; Kullar, R.; Ahrens, M. Patients' Hand Washing and Reducing HospitalAcquired Infection. Crit. Care Nurse 2017, 37, e1-e8. [CrossRef]

18. McBryde, E.S.; Bradley, L.C.; Whitby, M.; McElwain, D.L. An investigation of contact transmission of methicillin-resistant Staphylococcus aureus. J. Hosp. Infect. 2004, 58, 104-108. [CrossRef] [PubMed]

19. Raza, T.; Ullah, S.R.; Mehmood, K.; Andleeb, S. Vancomycin resistant Enterococci: A brief review. J. Pak. Med. Assoc. 2018, 68, 768-772.

20. European Centre for Disease Prevention and Control (ECDC). Surveillance of Antimicrobial Resistance in Europe Surveillance Report; ECDC: Stockholm, Sweden, 2018; Available online: https:/ /www.ecdc.europa.eu/sites/default/files/documents/surveillanceantimicrobial-resistance-Europe-2018.pdf (accessed on 6 June 2021).

21. Grundmann, H.; Glasner, C.; Albiger, B.; Aanensen, D.M.; Tomlinson, C.T.; Andrasević, A.T.; Cantón, R.; Carmeli, Y.; Friedrich, A.W.; Giske, C.G. Occurrence of carbapenemase-producing Klebsiella pneumoniae and Escherichia coli in the European survey of carbapenemase-producing Enterobacteriaceae (EuSCAPE): A prospective, multinational study. Lancet Infect. Dis. 2017, 17, 153-163. [CrossRef]

22. Segagni Lusignani, L.; Starzengruber, P.; Dosch, V.; Assadian, O.; Presterl, E.; Diab-Elschahawi, M. Molecular epidemiology of multidrug-resistant clinical isolates of Acinetobacter baumannii. Wien. Klin. Wochenschr. 2017, 129, 816-822. [CrossRef] [PubMed]

23. Ayobami, O.; Willrich, N.; Harder, T.; Okeke, N.; Eckmanns, T.; Markwart, R. The incidence and prevalence of hospital-acquired (carbapenem-resistant) Acinetobacter baumannii in Europe, Eastern Mediterranean and Africa: A systematic review and metaanalysis. Emerg. Microbes Infect. 2019, 8, 1747-1759. [CrossRef]

24. European Centre for Disease Prevention and Control (ECDC). Regional Outbreak of New Delhi Metallo-Betalactamase-Producing Carbapenem-Resistant Enterobacteriaceae, Italy, 2018-2019; ECDC: Stockholm, Sweden, 2019; Available online: https://www.ecdc europa.eu/sites / default / files / documents / 04-Jun-2019-RRA-Carbapenems\%2C\%20Enterobacteriaceae-Italy.pdf (accessed on 6 June 2021).

25. Tooke, C.L.; Hinchliffe, P.; Bragginton, E.C.; Colenso, C.K.; Hirvonen, V.H.A.; Takebayashi, Y.; Spencer, J. $\beta$-Lactamases and $\beta$-Lactamase Inhibitors in the 21st Century. J. Mol. Biol. 2019, 431, 3472-3500. [CrossRef] [PubMed]

26. Williams, M.M.; Armbruster, C.R.; Arduino, M.J. Plumbing of hospital premises is a reservoir for opportunistically pathogenic microorganisms: A review. Biofouling 2013, 29, 147-162. [CrossRef] [PubMed]

27. Decker, B.K.; Palmore, T.N. The role of water in healthcare-associated infections. Curr. Opin. Infect. Dis. 2013, 26, 345-351. [CrossRef]

28. Capelletti, R.V.; Moraes, Â.M. Waterborne microorganisms and biofilms related to hospital infections: Strategies for prevention and control in healthcare facilities. J. Water Health 2016, 14, 52-67. [CrossRef]

29. Bonadonna, L.; Memoli, G.; Chiaretti, G. Formazione di biofilm su materiali a contatto con acqua: Aspetti sanitari e tecnologici. In Rapporti ISTISAN 08/19; Istituto Superiore di Sanità: Roma, Italy, 2008.

30. Exner, M.; Kramer, A.; Lajoie, L.; Gebel, J.; Engelhart, S.; Hartemann, P. Prevention and control of health care-associated waterborne infections in health care facilities. Am. J. Infect. Control. 2005, 33, S26-S40. [CrossRef] [PubMed]

31. Loveday, H.P.; Wilson, J.A.; Kerr, K.; Pitchers, R.; Walker, J.T.; Browne, J. Association between healthcare water systems and Pseudomonas aeruginosa infections: A rapid systematic review. J. Hosp. Infect. 2014, 86, 7-15. [CrossRef]

32. Emmerson, A.M. Emerging waterborne infections in health-care settings. Emerg. Infect. Dis. 2001, 7, 272-276. [CrossRef]

33. Trautmann, M.; Lepper, P.M.; Haller, M. Ecology of Pseudomonas aeruginosa in the intensive care unit and the evolving role of water outlets as a reservoir of the organism. Am. J. Infect. Control. 2005, 33 (Suppl. 1), S41-S49. [CrossRef]

34. Jones, S. Hand hygiene and transmission of Pseudomonas aeruginosa on hands in a hospital environment. Infect. Prev. 2011, 12, 146-148. [CrossRef]

35. de Abreu, P.M.; Farias, P.G.; Paiva, G.S.; Almeida, A.M.; Morais, P.V. Persistence of microbial communities including Pseudomonas aeruginosa in a hospital environment: A potential health hazard. BMC Microbiol. 2014, 14, 118. [CrossRef]

36. Haley, C.E.; Cohen, M.L.; Halter, J.; Meyer, R.D. Nosocomial legionnaires' disease: A continuing common-source epidemic at Wadsworth Medical Center. Ann. Intern. Med. 1979, 90, 583-586. [CrossRef]

37. Kirby, B.D.; Snyder, K.M.; Meyer, R.D.; Finegold, S.M. Legionnaires' disease: Report of sixty-five nosocomially acquired cases and review of the literature. Medicine 1980, 59, 188-205. [CrossRef]

38. Parry, M.F.; Stampleman, L.; Hutchinson, J.H.; Folta, D.; Steinberg, M.G.; Krasnogor, L.J. Waterborne Legionella bozemanii and nosocomial pneumonia in immunosuppressed patients. Ann. Intern. Med. 1985, 103, 205-210. [CrossRef] 
39. Joly, J.R.; Alary, M. Occurrence of nosocomial Legionnaires' disease in hospitals with contaminated potable water supply. In Legionella: Current Status and Emerging Perspectives; Barbaree, J.M., Breiman, R.F., Dufour, A.P., Eds.; ASM Press: Washington, DC, USA, 1994; pp. 39-43.

40. World Health Organization (WHO). Legionella and the Prevention of Legionellosis; Bartram, J., Chartier, Y., Lee, J.V., Pond, K., Surman-Lee, S., Eds.; WHO: Geneva, Switzerland, 2007.

41. Pereira, A.C.; Ramos, B.; Reis, A.C.; Cunha, M.V. Non-Tuberculous Mycobacteria: Molecular and Physiological Bases of Virulence and Adaptation to Ecological Niches. Microorganisms 2020, 8, 1380. [CrossRef]

42. Briancesco, R.; Semproni, M.; Della Libera, S.; Sdanganelli, M.; Bonadonna, L. Non-tuberculous mycobacteria and microbial populations in drinking water distribution systems. Ann. Ist. Super. Sanita 2010, 46, 254-258. [CrossRef] [PubMed]

43. Falkinham, J.O., 3rd. Nontuberculous mycobacteria from household plumbing of patients with nontuberculous mycobacteria disease. Emerg. Infect. Dis. 2011, 17, 419-424. [CrossRef]

44. Briancesco, R.; Semproni, M.; Paradiso, R.; Bonadonna, L. Nontuberculous mycobacteria: An emerging risk in engineered environmental habitats. Ann. Microbiol. 2014, 64, 735-740. [CrossRef]

45. Anaissie, E.J.; Stratton, S.L.; Dignani, M.C.; Lee, C.; Summerbell, R.C.; Rex, J.R.; Monson, T.P.; Walsh, T.J. Pathogenic molds (including Aspergillus species) in hospital water distribution systems-a 3-year prospective study and clinical implication for patients with hematologic malignancies. Blood 2003, 101, 2542-2546. [CrossRef]

46. Green, B.J.; Tovey, E.R.; Sercombe, J.K.; Blachere, F.M.; Beezhold, D.H.; Schmechel, D. Airborne fungal fragments and allergenicity. Med. Mycol. 2006, 44, S245-S255. [CrossRef] [PubMed]

47. Moscato, U.; Borghini, A.; Teleman, A.A. HVAC Management in Health Facilities. In Indoor Air Quality in Healthcare Facilities; Capolongo, S., Settimo, G., Gola, M., Eds.; Springer Briefs in Public Health: Cham, Switzerland, 2017.

48. American Society of Heating, Refrigerating and Air-Conditioning Engineers (ASHRAE) ANSI/ASHRAE Standard 62.1. Ventilation for Acceptable Indoor Air Quality; American Society of Heating, Refrigeration, and Air-Conditioning Engineers: Atlanta, GA, USA, 2016.

49. Medical Advisory Secretariat. Air cleaning technologies: An evidence-based analysis. Ont. Health Technol. Assess. Ser. 2015, 5, $1-52$.

50. Pasquarella, C.; Barchitta, M.; D’Alessandro, D.; Cristina, M.L.; Mura, I.; Nobile, M.; Auxilia, F.; Agodi, A.; Gruppo Italiano di Studio sull'Igiene Ospedaliera- SItI (GISIO). Heating, ventilation and air conditioning (HVAC) system, microbial air contamination and surgical site infection in hip and knee arthroplasties: The GISIO-SItI Ischia study. Ann. Ig. 2018, 30, 22-35. [CrossRef]

51. Saran, S.; Gurjar, M.; Azim, A.; Maurya, I. Structural risk factors for hospital-acquired infections in intensive care unit. HERD 2020, 1-9. [CrossRef]

52. Hanssen, S.O. HVAC: The importance of clean intake section and dry filter in cold climate. Indoor Air 2004, 14 (Suppl. 17), $195-201$. [CrossRef] [PubMed]

53. Moscato, U.; Capolongo, S.; D’alessandro, D. Approfondimenti di Igiene ed Edilizia Ospedaliera. In Igiene, Medicina Preventiva e Sanità Pubblica; Ricciardi, G., Ed.; Idelson-Gnocchi: Naples, Italy, 2013.

54. Caggiano, G.; Napoli, C.; Coretti, C.; Lovero, G.; Scarafile, G.; De Giglio, O.; Montagna, M.T. Mold contamination in a controlled hospital environment: A 3-year surveillance in southern Italy. BMC Infect. Dis. 2014, 14, 595. [CrossRef] [PubMed]

55. Garcia-Cruz, C.P.; Najera Aguilar, M.J.; Arroyo-Helguera, O.E. Fungal and Bacterial Contamination on Indoor Surfaces of a Hospital in Mexico. Jundishapur J. Microbiol. 2012, 5, 460-464. [CrossRef]

56. Ricciardi, W.; Angelillo, I.F.; Brusaferro, S.; De Giusti, M.; De Vito, E.; Moscato, U.; Pavia, M.; Siliquini, R.; Villari, P. Igiene per le Professioni Sanitarie, II Edizione; Idelson-Gnocchi: Naples, Italy, 2019.

57. Obbard, J.; Fang, L. Airborne concentrations of bacteria in a hospital environment in Singapore. Water Air Soil Pollut. 2003, 144, 333-341. [CrossRef]

58. Taccone, F.S.; Van den Abeele, A.M.; Bulpa, P.; Misset, B.; Meersseman, W.; Cardoso, T.; Paiva, J.; Blasco-Navalpotro, M.; De Laere, E.; Dimopoulos, G.; et al. Epidemiology of invasive aspergillosis in critically ill patients: Clinical presentation, underlying conditions and outcomes. Crit. Care 2015, 19, 7. [CrossRef]

59. Fishman, J.A. Overview: Fungal infections in the transplant patient. Transpl. Infect. Dis. 2002, 4 (Suppl. 3) (Suppl. 3), 3-11. [CrossRef]

60. Kauffman, C.A.; Freifeld, A.G.; Andes, D.R.; Baddley, J.W.; Herwaldt, L.; Walker, R.C.; Alexander, B.D.; Anaissie, E.J.; Benedict, K.; Ito, J.I.; et al. Endemic fungal infections in solid organ and hematopoietic cell transplant recipients enrolled in the TransplantAssociated Infection Surveillance Network (TRANSNET). Transpl. Infect. Dis. 2014, 16, 213-224. [CrossRef]

61. Bonadonna, L.; Briancesco, R.; Coccia, A.M.; Di Napoli, I.; Ferrante, I.; Forgia, C.; Giacomelli, M.; Giorgi, D.A.; Meloni, P.; Palmieri, S.; et al. Indagini sulla presenza di microrganismi in ambiente ospedaliero e rischi correlati. In La Qualità Dell'aria Indoor: Attuale Situazione Nazionale e Comunitaria. L'esperienza del Gruppo di Studio Nazionale sull'Inquinamento Indoor, Proceedings of the Workshop: La Qualità Dell'aria Indoor, Istituto Superiore di Sanità, Roma, 28 Maggio 2014; Santarsiero, A., Musmeci, L., Fuselli, S., e Gruppo di Studio Nazionale sull'Inquinamento Indoor, Eds.; Rapporti ISTISAN 15/4; Istituto Superiore di Sanità: Roma, Italy, 2015; pp. 102-108.

62. Stephens, B.; Azimi, P.; Thoemmes, M.S.; Heidarinejad, M.; Allen, J.G.; Gilbert, J.A. Microbial exchange via fomites and implications for human health. Curr. Pollut. Rep. 2019, 5, 198-213. [CrossRef] 
63. Godič Torkar, K.; Ivić, S. Surveillance of bacterial colonisation on contact surfaces in different medical wards. Arh. Hig. Toksikol. 2017, 68, 116-126. [CrossRef] [PubMed]

64. D’Souza, A.W.; Potter, R.F.; Wallace, M.; Shupe, A.; Patel, S.; Sun, X.; Gul, D.; Kwon, J.H.; Andleeb, S.; Burnham, C.A.D.; et al. Spatiotemporal dynamics of multidrug resistant bacteria on intensive care unit surfaces. Nat. Commun. 2019, 10, 4569. [CrossRef] [PubMed]

65. Chaoui, L.; Mhand, R.; Mellouki, F.; Rhallabi, N. Contamination of the Surfaces of a Health Care Environment by MultidrugResistant (MDR) Bacteria. Int. J. Microbiol. 2019, 29, 3236526. [CrossRef] [PubMed]

66. De Oliveira, A.C.; Damasceno, Q.S. Surfaces of the hospital environment as possible deposits of resistant bacteria: A review. Rev. Esc. Enferm. USP 2010, 44, 1118-1123. [CrossRef] [PubMed]

67. Sears, D.; Schwartz, B.S. Candida auris: An emerging multidrug-resistant pathogen. Int. J. Infect. Dis. 2017, 63, 95-98. [CrossRef]

68. Hlophe, S.T.; McKerrow, N. Hospital-acquired Klebsiella pneumoniae infections in a paediatric intensive care unit. S. Afr. J. Child Health 2014, 8, 125-128. [CrossRef]

69. Jin., C.; Shi, R.; Jiang, X.; Zhou, F.; Qiang, J.; An, C. Epidemic Characteristics of Carbapenem-Resistant Klebsiella pneumoniae in the Pediatric Intensive Care Unit of Yanbian University Hospital, China. Infect. Drug. Resist. 2020, 13, 1439-1446. [CrossRef]

70. Lemmen, S.W.; Häfner, H.; Zolldann, D.; Stanzel, S.; Lütticken, R. Distribution of multiresistant Gram negative versus Grampositive bacteria in the hospital inanimate environment. J. Hosp. Infect. 2004, 56, 191-197. [CrossRef]

71. Walker, J.; Moore, G.; Collins, S.; Parks, S.; Garvey, M.I.; Lamagni, T.; Smith, G.; Dawkin, L.; Goldenberg, S.; Chand, M. Microbiological problems and biofilms associated with Mycobacterium chimaera in heater-cooler units used for cardiopulmonary bypass. J. Hosp. Infect. 2017, 96, 209-220. [CrossRef]

72. Schreiber, P.W.; Sax, H. Nosocomial and healthcare related infections Mycobacterium chimaera infections associated with heatercooler units in cardiac surgery. Curr. Opin. Infect. Dis. 2017, 30, 388-394. [CrossRef]

73. van Ingen, J.; Kohl, T.A.; Kranzer, K.; Hasse, B.; Keller, P.M.; Katarzyna Szafrańska, A.; Hillemann, D.; Chand, M.; Schreiber, P.W.; Sommerstein, R.; et al. Global outbreak of severe Mycobacterium chimaera disease after cardiac surgery: A molecular epidemiological study. Lancet Infect. Dis. 2017, 17, 1033-1041. [CrossRef]

74. Cappabianca, G.; Paparella, D.; D’Onofrio, A.; Caprili, L.; Minniti, G.; Lanzafame, M.; Parolari, A.; Musumeci, F.; Beghi, C. Mycobacterium chimaera infections following cardiac surgery in Italy: Results from a National Survey Endorsed by the Italian Society of Cardiac Surgery. J. Cardiovasc. Med. 2018, 19, 748-755. [CrossRef] [PubMed]

75. Hanczvikkel, A.; Tóth, Á. Quantitative study about the role of environmental conditions in the survival capability of multidrugresistant bacteria. J. Infect. Public Health 2018, 11, 801-806. [CrossRef] [PubMed]

76. Katzenberger, R.H.; Rösel, A.; Vonberg, R.P. Bacterial survival on inanimate surfaces: A field study. BMC Res. Notes 2021, 4, 97. [CrossRef]

77. Bravo, Z.; Orruño, M.; Navascues, T.; Ogayara, E.; Ramos-Vivasb, J.; Kaberdin, V.R.; Arana, I. Analysis of Acinetobacter baumannii survival in liquid media and on solid matrices as well as effect of disinfectants. J. Hosp. Infect. 2019, 103, e42-e52. [CrossRef] [PubMed]

78. Walther, B.A.; Ewald, P.W. Pathogen survival in the external environment and the evolution of virulence. Biol. Rev. Camb. Philos. Soc. 2004, 79, 849-869. [CrossRef] [PubMed]

79. Drabick, J.A.; Gracely, E.J.; Heidecker, G.J.; LiPuma, J.J. Survival of Burkholderia cepacia on dry environmental surfaces. J. Hosp. Infect. 1996, 32, 267-277. [CrossRef]

80. Kusumaningrum, H.D.; Riboldi, G.; Hazeleger, W.C.; Beumer, R.R. Survival of foodborne pathogens on stainless steel surfaces and cross-contamination to foods. Int. J. Food Microbiol. 2003, 85, 227-236. [CrossRef]

81. Falsey, A.R.; Walsh, E.E. Transmission of Chlamydia pneumoniae. J. Infect. Dis. 1993, 168, 493-496. [CrossRef]

82. Novak, K.D.; Kowalski, R.P.; Karenchak, L.M.; Gordon, Y.J. Chlamydia trachomatis can be transmitted by a nonporous plastic surface in vitro. Cornea 1995, 14, 523-526. [CrossRef]

83. Wendel, K.A. Diseases due to other category B bacterial pathogens II: Psittacosis, Q fever and typhus. In Biodefense: Principles and Pathogens; Bronze, M.S., Greenfield, R.A., Eds.; Horizon Bioscience: Norfolk, VA, USA, 2005; pp. $493-498$.

84. Weber, D.J.; Rutala, W.A.; Miller, M.B.; Huslage, K.; Sickebert-Bennet, E. Role of hospital surfaces in the transmission of health care-associated pathogens: Norovirus, Clostridium difficile and Acinetobacter species. Am. Infect. Control. 2010, 38, S25-S33. [CrossRef]

85. Augustine, J.L.; Renshaw, H.W. Survival of Corynebacterium pseudotuberculosis in axenic purulent exudate on common barnyard fomites. Am. J. Vet. Res. 1986, 47, 713-715.

86. Noskin, G.A.; Stosor, V.; Cooper, I.; Peterson, L.R. Recovery of vancomycin- resistant enterococci on fingertips and environmental surfaces. Infect. Control Hosp. Epidemiol. 1995, 16, 577-581. [CrossRef] [PubMed]

87. Wendt, C.; Wiesenthal, B.; Dietz, E.; Rüden, H. Survival of vancomycin-resistant and vancomycin-susceptible enterococci on dry surfaces. J. Clin. Microbiol. 1998, 36, 3734-3736. [CrossRef] [PubMed]

88. Neely, A.N.; Maley, M.P. Survival of enterococci and staphylococci on hospital fabric and plastic. J. Clin. Microbiol. 2000, 38, 724-726. [CrossRef] [PubMed]

89. Wagenvoort, H.T.; De Brauwer, E.I.G.B.; Penders, R.J.R.; Willems, R.J.; Top, J.; Bonten, M.J. Environmental survival of vancomycinresistant Enterococcus faecium. J. Hosp. Infect. 2011, 77, 274-283. [CrossRef] 
90. Wilks, S.A.; Michels, H.; Keevil, C.W. The survival of Escherichia coli O157 on a range of metal surfaces. Int. J. Food Microbiol. 2005, 105, 445-454. [CrossRef]

91. Siroli, L.; Patrignani, F.; Serrazanetti, D.I.; Chiavari, C.; Benevelli, M.; Grazia, L.; Lanciotti, R. Survival of Spoilage and Pathogenic Microorganisms on Cardboard and Plastic Packaging Materials. Front. Microbiol. 2017, 8, 2606. [CrossRef]

92. West, A.P.; Millar, M.R.; Tomkins, D.S. Effect of physical environment on survival of Helicobacter Pylori. J. Clin. Pathol. 1992, 45, 228-231. [CrossRef] [PubMed]

93. Hirai, Y. Survival of bacteria under dry conditions; from a viewpoint of nosocomial infection. J. Infect. Dis. 1991, 19, 191-200. [CrossRef]

94. Neely, A.N. A Survey of Gram-Negative Bacteria Survival on Hospital Fabrics and Plastics. J. Burn. Care Rehabil. 2000, 21, 523-527. [CrossRef]

95. Otter, J.A.; French, G.L. Survival of nosocomial bacteria and spores on surfaces and inactivation by hydrogen peroxide vapor. J. Clin. Microbiol. 2009, 47, 205-207. [CrossRef] [PubMed]

96. Esteves, D.C.; Pereira, V.C.; Souza, J.M.; Keller, R.; Simões, R.D.; Winkelstroter Eller, L.K.; Rodrigues, M.V.P. Influence of bioloical fluids in bacterial viability on different hospital surfaces and fomites. Am. J. Infect. Control. 2016, 44, 311-314. [CrossRef]

97. Wilks, S.A.; Michels, H.T.; Keevil, C.W. Survival of Listeria monocytogenes Scott A on metal surfaces: Implications for crosscontamination. Int. J. Food Microbiol. 2006, 111, 82-93. [CrossRef] [PubMed]

98. Mitscherlich, E.; Marth, E.H. Microbial Survival in the Environment; Springer: Berlin/Heidelberg, Germany, 1984.

99. Pérez, J.L.; Gómez, E.; Sauca, G. Survival of gonococci from urethral discharge on fomites. Eur. J. Clin. Microbiol. Infect. Dis. 1990, 9,54-55. [CrossRef]

100. Tzeng, Y.L.; Martin, L.E.; Stephens, D.S. Environmental survival of Neisseria meningitidis. Epidemiol. Infect. 2014, 1042, 187-190. [CrossRef] [PubMed]

101. Koca, O.; Altoparlak, U.; Ayyildiz, A.; Kaynar, H. Persistence of nosocomial pathogens on various fabrics. Eurasian J. Med. 2012, 44, 28-31. [CrossRef] [PubMed]

102. Scott, E.; Bloomfield, S.F. The survival and transfer of microbial contamination via cloths, hands and utensils. J. Appl. Bacteriol. 1990, 68, 271-278. [CrossRef]

103. Finn, S.; Händler, K.; Condell, O.; Colgan, A.; Cooney, S.; McClure, P.; Amézquita, A.; Hinton, J.C.D.; Fanning, S. ProP is required for the survival of desiccated Salmonella enterica serovar typhimurium cells on a stainless steel surface. Appl. Environ. Microbiol. 2013, 79, 4376-4384. [CrossRef]

104. Ramachandran, G.; Aheto, K.; Shirtliff, M.E.; Tennant, S.M. Poor biofilm-forming ability and long-term survival of invasive Salmonella typhimurium ST313. Pathog Dis. 2016, 74, ftw049. [CrossRef]

105. Margas, E.; Meneses, N.; Conde-Petit, B.; Dodd, C.E.R.; Holah, J. Survival and death kinetics of Salmonella strains at low relative humidity, attached to stainless steel surfaces. Int. J. Food Microbiol. 2014, 187, 33-40. [CrossRef] [PubMed]

106. Islam, M.S.; Hossain, M.A.; Khan, S.I.; Khan, M.N.H.; Sack, R.B.; Albert, M.J.; Huq, A.; Colwell, R.R. Survival of Shigella dysenteriae Type 1 on Fomites. J. Health Popul. Nutr. 2001, 19, 177-182. [PubMed]

107. Huang, R.; Mehta, S.; Weed, D.; Price, C.S. Methicillin-resistant Staphylococcus aureus survival on hospital fomites. Infect. Control Hosp. Epidemiol. 2006, 27, 1267-1269. [CrossRef]

108. Petti, S.; De Giusti, M.; Moroni, C.; Polimeni, A. Long-term survival curve of methicillin resistant Staphylococcus aureus on clinical contact surfaces in natural-like conditions. Am. J. Infect. Control 2012, 40, 1010-1012. [CrossRef] [PubMed]

109. Walsh, R.L.; Camilli, A. Streptococcus pneumoniae is desiccation tolerant and infectious upon rehydration. MBio 2011, 2, e00092-11. [CrossRef]

110. Marks, L.R.; Reddinger, R.M.; Hakansson, A.P. Biofilm formation enhances fomite survival of Streptococcus pneumonia and Streptococcus pyogenes. Infect. Immun. 2014, 82, 1141-1146. [CrossRef]

111. Wagenvoort, J.H.; Penders, R.J.; Davies, B.I.; Lutticken, R. Similar environmental survival patterns of Streptococcus pyogenes strains of different epidemiologic backgrounds and clinical severity. Eur. J. Clin. Microbiol. Infect. Dis. 2005, 24, 65-67. [CrossRef] [PubMed]

112. Rose, L.J.; Donlan, R.; Banerjee, S.N.; Arduino, S.M. Survival of Yersinia pestis on environmental surfaces. Appl. Environ. Microbiol. 2003, 69, 2166-2171. [CrossRef]

113. Rangel-Frausto, M.S.; Houston, A.K.; Bale, M.J.; Fu, C.; Wenzel, R.P. An experimental model for study of Candida survival and transmission in human volunteers. Eur. J. Clin. Microbioland Infect. Dis. 1994, 13, 590-595. [CrossRef] [PubMed]

114. Traoré, O.; Springthorpe, V.S.; Sattar, S.A. A quantitative study of the survival of two species of Candida on porous and non-porous environmental surfaces and hands. J. Appl. Microbiol. 2002, 92, 549-555. [CrossRef]

115. Piedrahita, C.T.; Cadnum, J.L.; Jencson, A.L.; Shaikh, A.A.; Ghannoum, M.A.; Donskey, C.J. Environmental Surfaces in Healthcare Facilities are a Potential Source for Transmission of Candida auris and Other Candida Species. Infect. Control Hosp. Epidemiol. 2017, 38, 1107-1109. [CrossRef]

116. Welsh, R.M.; Bentz, M.L.; Shams, A.; Houston, H.; Lyons, A.; Rose, L.J.; Litvintseva, A.P. Survival, Persistence, and Isolation of the Emerging Multidrug-Resistant Pathogenic Yeast Candida auris on a Plastic Health Care Surface. J. Clin. Microbiol. 2017, 55, 2996-3005. [CrossRef]

117. Short, B.; Brown, J.; Delaney, C.; Sherry, L.; Williams, C.; Ramage, G.; Kean, R. Candida auris exhibits resilient biofilm characteristics in vitro: Implications for environmental persistence. J. Hosp. Infect. 2019, 103, 92-96. [CrossRef] 
118. Lamarre, C.; Sokol, S.; Debeaupuis, J.P.; Henry, C.; Lacroix, C.; Glaser, P.; Coppée, J.Y.; François, J.M.; Latgé, J.P. Transcriptomic analysis of the exit from dormancy of Aspergillus fumigatus conidia. BMC Genom. 2008, 9, 417. [CrossRef]

119. Novodvorska, M.; Stratford, M.; Blythe, M.J.; Wilson, R.; Beniston, R.G.; Archer, D.B. Metabolic activity in dormant conidia of Aspergillus niger and developmental changes during conidial outgrowth. Fungal. Genet. Biol. 2016, 94, 23-31. [CrossRef]

120. Neely, A.N.; Orloff, M.M. Survival of Some Medically Important Fungi on Hospital Fabrics and Plastics. J. Clin. Microbiol. 2001, 39, 3360-3361. [CrossRef]

121. Weaver, L.; Michels, H.T.; Keevil, C.W. Potential for preventing spread of fungi in air-conditioning systems constructed using copper instead of aluminum. Lett. Appl. Microbiol. 2010, 50, 18-23. [CrossRef]

122. Gupta, M.; Bisesi, M.; Lee, J. Comparison of survivability of Staphylococcus aureus and spores of Aspergillus niger on commonly used floor materials. Am. J. Infect. Control 2017, 45, 717-722. [CrossRef] [PubMed]

123. Nelson, P.E.; Dignani, M.C.; Anaissie, E.J. Taxonomy, Biology, and Clinical Aspects of Fusarium Species. J. Clin. Microbiol. 1994, 7, 479-504. [CrossRef] [PubMed]

124. Hara, J.; Okomator, S.; Minekawa, Y.; Yamazaki, K.; Kase, T. Survival and disinfection of adenovirus type 19 and enterovirus 70 in ophthalmic practice. Jpn. J. Ophthalmol. 1990, 34, 421-427. [PubMed]

125. Mahl, M.C.; Sadler, C. Virus survival on inanimate surfaces. Can. J. Microbiol. 1975, 21, 819-823. [CrossRef]

126. Abad, F.X.; Villena, C.; Guix, S.; Caballero, S.; Pintó, R.M.; Bosch, A. Potential role of fomites in the vesicular transmission of human astroviruses. Appl. Environ. Microbiol. 2001, 67, 3904-3907. [CrossRef] [PubMed]

127. Wladowetz, V.W.; Dmitrijewa, R.A.; Safjulin, A.A. Die Persistenz von Viren auf Oberflächen und die Anwendung der UV-Bestrahlung zur Virusdesinfektion. Z. Gesamte Hyg. 1974, 7, 173-176.

128. Gordon, Y.J.; Gordon, R.Y.; Romanowski, E.; Araullo-Cruz, T.P. Prolonged recovery of desiccated adenoviral serotypes 5, 8, and 19 from plastic and metal surfaces in vitro. Ophthalmology 1993, 100, 1835-1839. [CrossRef]

129. Abad, F.X.; Pinto, R.M.; Bosch, A. Survival of enteric viruses on environmental fomites. Appl. Environ. Microbiol. 1994, 60, 3704-3710. [CrossRef]

130. Gerth, H.J. Viren und virale Erkrankungen. In Hygiene und Infektionen im Krankenhaus; Thofern, E., Botzenhart, K., Eds.; Fischer: Stuttgart, Germany, 1983; pp. 55-106.

131. Rabenau, H.F.; Cinatl, J.; Morgenstern, B.; Bauer, G.; Preiser, W.; Doerr, H.W. Stability and inactivation of SARS coronavirus. Med. Microbiol. Immunol. 2005, 194, 1-6. [CrossRef]

132. Kim, S.J.; Si, J.; Lee, J.E.; Ko, G. Temperature and humidity influences on inactivation kinetics of enteric viruses on surfaces. Environ. Sci. Technol. 2012, 46, 13303-13310. [CrossRef]

133. D'Souza, D.H.; Sair, A.; Williams, K.; Papafragkou, E.; Jean, J.; Moore, C.; Jaykus, L. Persistence of caliciviruses on environmental surfaces and their transfer to food. Int. J. Food Microbiol. 2006, 108, 84-91. [CrossRef]

134. Clay, S.; Maherchandani, S.; Malik, Y.S.; Goyal, S.M. Survival on uncommon fomites of feline calicivirus, a surrogate of noroviruses. Am. J. Infect. Control 2006, 34, 41-43. [CrossRef]

135. Arthur, S.E.; Gibson, K.E. Environmental persistence of Tulane virus-A surrogate for human norovirus. Can. J. Microbiol. 2016, 62, 449-454. [CrossRef]

136. Warnes, S.L.; Keevil, C.W. Inactivation of norovirus on dry copper alloy surfaces. PloS ONE 2013, 8, e75017. [CrossRef]

137. Buckley, D.; Fraser, A.; Huang, G.; Jiang, X. Recovery Optimization and Survival of the Human Norovirus Surrogates Feline Calicivirus and Murine Norovirus on Carpet. Appl. Environ. Microbiol. 2017, 83, e01336-17. [CrossRef]

138. Sizun, J.; Yu, M.W.; Talbot, P.J. Survival of human coronaviruses $229 \mathrm{E}$ and OC43 in suspension and after drying on surfaces: A possible source of hospital-acquired infections. J. Hosp. Infect. 2000, 46, 55-60. [CrossRef] [PubMed]

139. Gagneur, A.; Legrand, M.C.; Picard, B.; Baron, R.; Talbot, P.J.; de Parscau, L.; Sizun, J. Nosocomial infections due to human coronaviruses in the newborn. Arch. Pediatr. 2002, 9, 61-69. [CrossRef]

140. Van Doremalen, N.; Bushmaker, T.; Morris, D.H.; Holbrook, M.G.; Gamble, A.; Williamson, B.N.; Tamin, A.; Harcourt, J.L.; Thornburg, N.J.; Gerber, S.I.; et al. Aerosol and surface stability of SARS-CoV-2 as compared with SARS-CoV-1. N. Engl. J. Med. 2020, 382, 1564-1567. [CrossRef] [PubMed]

141. Chin, A.W.H.; Chu, J.T.S.; Perera, M.R.A.; Hui, K.P.Y.; Yen, H.; Chan, M.C.W.; Peiris, M.; Poon, L.L.M. Stability of SARS-CoV-2 in different environmental conditions. Lancet Microbe 2020, 1, e10. [CrossRef]

142. Kratzel, A.; Steiner, S.; Todt, D.; V'kovski, P.; Brueggemann, Y.; Steinmann, J.; Steinmann, E.; Thiel, V.; Pfaender, S. Temperaturedependent surface stability of SARS-CoV-2. J. Infect. 2020, 81, 452-482. [CrossRef]

143. Kampf, G.; Todt, D.; Pfaender, S.; Steinmann, E. Persistence of coronaviruses on inanimate surfaces and their inactivation with biocidal agents. J. Hosp. Infect. 2020, 104, 246-251. [CrossRef] [PubMed]

144. Marzoli, F.; Bortolami, A.; Pezzuto, A.; Mazzetto, E.; Piro, R.; Terregino, C.; Bonfante, F.; Belluco, S. A systematic review of human coronaviruses survival on environmental surfaces. Sci. Total Environ. 2021, 778, 146191. [CrossRef] [PubMed]

145. Duan, S.M.; Zhao, X.S.; Wen, R.F.; Huang, J.J.; Pi, G.H.; Zhang, S.X.; Han, J.; Bi, S.L.; Ruan, L.; Dong, X.P. Stability of SARS coronavirus in human specimens and environment and its sensitivity to heating and UV irradiation. Biomed. Environ. Sci. 2003, 16, 246-255.

146. Van Doremalen, N.; Bushmaker, T.; Munster, V.J. Stability of Middle East respiratory syndrome coronavirus (MERS-CoV) under different environmental conditions. Eurosurveillance 2013, 18. [CrossRef] [PubMed] 
147. Otter, J.A.; Donskey, C.; Yezli, S.; Douthwaite, S.; Goldenberg, S.D.; Weber, D.J. Transmission of SARS and MERS coronaviruses and influenza virus in healthcare settings: The possible role of dry surface contamination. J. Hosp. Infect. 2016, 92, 235-250. [CrossRef] [PubMed]

148. Lai, M.Y.Y.; Cheng, P.K.C.; Lim, W.W.L. Survival of Severe Acute Respiratory Syndrome Coronavirus. Clin. Infect. Dis. 2005, 41, e67-e71. [CrossRef]

149. Müller, A.; Tillmann, R.L.; Simon, A.; Schildgen, O. Stability of human metapneumovirus and human coronavirus NL63 on medical instruments and in the patient environment. J. Hosp. Infect. 2008, 69, 406-408. [CrossRef]

150. Warnes, S.L.; Little, Z.R.; Keevil, C.W. Human coronavirus 229E remains infectious on common touch surface materials. Mbio 2015, 6, e01697-15. [CrossRef]

151. Firquet, S.; Beaujard, S.; Lobert, P.-E.; Sané, F.; Caloone, D.; Izard, D.; Hober, D. Survival of Enveloped and Non-Enveloped Viruses on Inanimate Surfaces. Microbes Environ. 2015, 30, 140-144. [CrossRef]

152. Faix, R.G. Survival of cytomegalovirus on environmental surfaces. J. Pediatr. 1984, 106, 649-652. [CrossRef]

153. Faix, R.G. Comparative Efficacy of Handwashing Agents against Cytomegalovirus. Infect. Control 1987, 158-162. [CrossRef]

154. Mocé-Llivina, L.; Papageorgiou, G.T.; Jofre, J. A membrane-based quantitative carrier test to assess the virucidal activity of disinfectants and persistence of viruses on porous fomites. J. Virol. Methods 2006, 135, 49-55. [CrossRef]

155. Westhoff Smith, D.; Hill-Batorski, L.; N'jai, A.; Eisfeld, A.J.; Neumann, G.; Halfmann, P.; Kawaoka, Y. Ebola Virus Stability under Hospital and Environmental Conditions. J. Infect. Dis. 2016, 214, S142-S144. [CrossRef] [PubMed]

156. Piercy, T.J.; Smither, S.J.; Steward, J.A.; Eastaugh, L.; Lever, M.S. The survival of filoviruses in liquids, on solid substrates and in a dynamic aerosol. J. Appl. Microbiol. 2010, 109, 1531-1539. [CrossRef]

157. Mbithi, J.N.; Springthorpe, V.S.; Sattar, S.A. Effect of relative humidity and air temperature on survival of hepatitis A virus on environmental surfaces. Appl. Environ. Microbiol. 1991, 57, 1394-1399. [CrossRef]

158. Bond, W.W.; Favero, M.S.; Petersen, N.J.; Gravelle, C.R.; Ebert, J.W.; Maynard, J.E. Survival of hepatitis B virus after drying and storage for one week. Lancet 1981, I, 550-551. [CrossRef]

159. Favero, M.S.; Bond, W.W.; Petersen, N.J.; Berquist, K.R.; Maynard, J.E. Detection Methods for Study of the Stabillity of Hepatitis B Antigen on Surfaces. J. Infect. Dis. 1974, 129, 210-212. [CrossRef] [PubMed]

160. Paintsil, E.; Binka, M.; Patel, A.; Lindenbach, B.D.; Heimer, R. Hepatitis C virus maintains infectivity for weeks after drying on inanimate surfaces at room temperature: Implications for risks of transmission. J. Infect. Dis. 2014, 209, 1205-1211. [CrossRef]

161. Doerrbecker, J.; Friesland, M.; Ciesek, S.; Erichsen, T.J.; Mateu-Gelabert, P.; Steinmann, J.; Steinmann, J.; Pietschmann, T.; Steinmann, E. Inactivation and survival of hepatitis C virus on inanimate surfaces. J. Infect. Dis. 2011, 204, 1830-1838. [CrossRef]

162. Carducci, A.; Verani, M.; Casini, B.; Giuntini, A.; Mazzoni, F.; Rovini, E.; Passaglia, A.; Giusti, L.; Valenza, A.; Lombardi, R. Detection and potential indicators of the presence of hepatitis $\mathrm{C}$ virus on surfaces in hospital settings. Lett. Appl. Microbiol. 2002, 34, 189-193. [CrossRef] [PubMed]

163. Rheinbaben, F.V.; Wolff, M.H. Virusdesinfektion. In Handbuch der Viruswirksamen Desinfektion; Springer: Berlin/Heidelberg, Germany, 2002; pp. 266-282.

164. Tjotta, E.; Hungnes, O.; Grinde, B. Survival of HIV-1: Activity after disinfection, temperature and pH changes, or drying. J. Med. Virol. 1991, 35, 223-227. [CrossRef]

165. Barré-Sinoussi, F.; Nugeyre, M.T.; Chermann, J.C. Resistance of AIDS virus at room temperature. Lancet 1985, II, 721-722. [CrossRef]

166. Nerurkar, L.S.; West, F.; May, M.; Madden, D.L.; Sever, J.L. Survival of herpes simplex virus in water specimens collected from hot spa facilities and on plastic surfaces. JAMA 1983, 250, 3081-3083. [CrossRef] [PubMed]

167. Tollefson, S.J.; Cox, R.G.; Williams, J.V. Studies of culture conditions and environmental stability of human metapneumovirus. Virus Res. 2010, 151, 54-59. [CrossRef] [PubMed]

168. Bean, B.; Moore, B.M.; Sterner, B.; Peterson, L.R.; Gerding, D.N.; Balfour, H.H. Survival of influenza viruses an environmental surfaces. J. Infect. Dis. 1982, 146, 47-51. [CrossRef]

169. Brady, M.T.; Evans, J.; Cuartes, J. Survival and disinfection of parainfluenza viruses on environmental surfaces. Am. J. Infect. Control. 1990, 18, 18-23. [CrossRef]

170. Pirtle, E.C.; Beran, G.W. Virus survival in the environment. Rev. Sci. Tech. 1991, 10, 733-748. [CrossRef]

171. Thompson, K.-A.; Bennett, A.M. Persistence of influenza on surfaces. J. Hosp. Infect. 2017, 95, 194-199. [CrossRef]

172. Greatorex, J.S.; Digard, P.; Curran, M.D.; Moynihan, R.; Wensley, H.; Wreghitt, T.; Varsani, H.; Garcia, F.; Enstone, J.; Nguyen-VanTa, J.S. Survival of influenza A(H1N1) on materials found in households: Implications for infection control. PloS ONE 2011, 6, e27932. [CrossRef]

173. Roden, R.B.S.; Lowy, D.R.; Schiller, J.T. Papillomavirus is resistant to desiccation. J. Infect. Dis. 1997, 176, 1076-1079. [CrossRef] [PubMed]

174. Tamrakar, S.B.; Henley, J.; Gurian, P.L.; Gerba, C.P.; Mitchell, J.; Enger, K.; Rose, G.B. Persistence analysis of poliovirus on three different types of fomites. J. Appl. Microbiol. 2017, 122, 522-530. [CrossRef]

175. Wood, J.P.; Choi, Y.W.; Wendling, M.Q.; Rogers, J.V.; Chappie, D.J. Environmental persistence of vaccinia virus on materials. Lett. Appl. Microbiol. 2013, 57, 399-404. [CrossRef]

176. Schoenbaum, M.A.; Freund, J.D.; Beran, G.W. Survival of pseudorabies virus in the presence of selected diluents and fomites. J. Am. Vet. Med. Assoc. 1991, 198, 1393-1397. [PubMed] 
177. Hall, C.B.; Douglas, R.G.; Geiman, J.M. Possible transmission by fomites of respiratory syncytial virus. J. Infect. Dis. 1980, 141, 98-102. [CrossRef]

178. Sattar, S.A.; Karim, Y.G.; Springthorpe, V.S.; Johnson-Lussenburg, C.M. Survival of human rhinovirus type 14 dried onto nonporous inanimate surfaces: Effect of relative humidity and suspending medium. Can. J. Microbiol. 1987, 33, 802-806. [CrossRef] [PubMed]

179. Reed, S.E. An investigation of the possible transmission of rhinovirus colds through direct contact. Epidemiol. Infect. 1975, 75, 249-258.

180. Ansari, S.A.; Springthorpe, V.S.; Sattar, S.A. Survival and vehicular spread of human rotaviruses: Possible relation to seasonality of outbreaks. Rev. Infect. Dis. 1991, 13, 448-461. [CrossRef] [PubMed]

181. Sattar, S.; Lloyd-Evans, N.; Springthorpe, V.S. Institutional outbreaks of rotavirus diarrhoea: Potential role of fomites and environmental surfaces as vehicles for virus transmission. Epidemiol. Infect. 1986, 96, 277-289. [CrossRef] [PubMed]

182. Keswick, B.H.; Pickering, L.; DuPont, H.L.; Woodward, W.E. Survival and Detection of Rotaviruses on Environmental Surfaces in Day Care Centers. Appl. Environ. Microbiol. 1983, 46, 813-816. [CrossRef]

183. Moe, K.; Shirley, J.A. The Effects of Relative Humidity and Temperature on the Survival of Human Rotavirus in Faeces. Arch. Virol. 1982, 72, 179-186. [CrossRef]

184. Mahnel, H. Experimentelle Ergebnisse über die Stabilität von Pockenviren unter Labor- und Umweltbedingungen. Zent. Vet. 1987, 34, 449-464.

185. World Health Organization (WHO). Guidelines on Core Components of Infection Prevention and Control Programs at the National and Acute Health Care Facility Level; WHO: Geneva, Switzerland, 2016.

186. Cassini, A.; Plachouras, D.; Eckmanns, T.; Abu Sin, M.; Blank, H.P.; Ducomble, T.; Haller, S.; Harder, T.; Klingeberg, A.; Sixtensson, M.; et al. Burden of Six Healthcare-Associated Infections on European Population Health: Estimating Incidence-Based Disability Adjusted Life Years through a Population Prevalence-Based Modelling Study. PLoS Med. 2016, 13, e1002150. [CrossRef]

187. Istituto Superiore di Sanità. Infezioni Correlate All'assistenza, Aspetti Epidemiologici. Available online: http://www.epicentro. iss.it/problemi/infezioni_correlate/epid.asp (accessed on 10 April 2021).

188. Bonadonna, L.; Cannarozzi de Grazia, M.; Capolongo, S.; Casini, B.; Cristina, M.L.; Daniele, G.; D’Alessandro, D.; De Giglio, O.; Di Benedetto, A.; Di Vittorio, G.; et al. Water safety in healthcare facilities. The Vieste Charter. Ann. Ig. 2017, 29, 92-100. [CrossRef]

189. Caselli, E.; D’Accolti, M.; Vandini, A.; Lanzoni, L.; Camerada, M.T.; Coccagna, M.; Branchini, A.; Antonioli, P.; Balboni, P.G.; Di Luca, D.; et al. Impact of a probiotic-based cleaning intervention on the microbiota ecosystem of the hospital surfaces: Focus on the resistome remodulation. PLoS ONE 2016, 11, e0148857. [CrossRef] [PubMed]

190. Center of Disease Control (CDC). Guidelines for environmental infection control in health-care facilities. In Recommendations of CDC and the Healthcare Infection Control Practices Advisory Committee; CDC: Atlanta, GA, USA, 2019.

191. European Centre for Disease Prevention and Control (ECDC). Legionnaires' disease. In Annual Epidemiological Report for 2015; ECDC, Ed.; ECDC: Stockholm, Sweden, 2017.

192. Centers for Disease Control (CDC). Guidelines for environmental infection control in health-care facilities. In Morbidity and Mortality Weekly Report (MMWR); No. RR-10; CDC: Atlanta, GA, USA, 2003; Volume 52. 